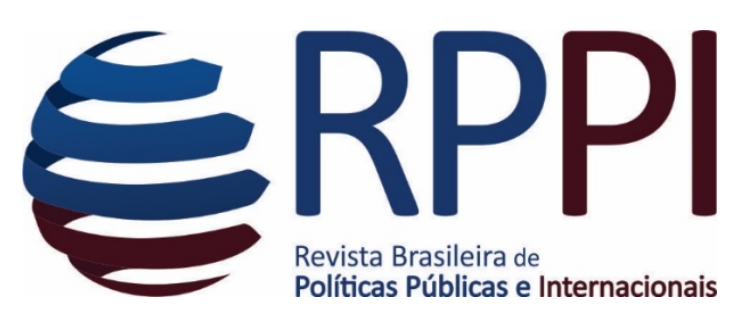

Data de recebimento: 28/07/2017

Data de aceite: 16/03/2018

Organização: Programa de Pós-Graduação em

Gestão Pública e Cooperação Internacional

(PGPCI/UFPB)

Avaliação: Por Pares.

\title{
Disputas e Barreiras Não-Tarifárias no Comércio Agrícola: as exportações de carne bovina brasileira entre 2006 e 2015
}

\section{Disputes and Non Tariffs Barriers on Agricultural Trade: the exports of Brazilian beef between 2006 and 2015}

\author{
Andressa Ramos Vieira Vale \\ Economista pela Universidade Federal do Paraná (UFPR). \\ Email: andressa-gnr@hotmail.com \\ Wellington Pereira \\ Professor da Universidade Federal do Paraná (UFPR). \\ Email: wdspereira@ufpr.br / wdspereira@yahoo.com.br
}

Resumo: O Brasil é o segundo maior produtor de carne bovina do mundo e lidera o ranking internacional dessas exportações desde 2008. Junto a outros países em desenvolvimento, as exportações brasileiras de produtos agropecuários também sofrem com práticas concorrenciais amparadas em barreiras não-tarifárias. O objetivo deste artigo é discutir as características do novo protecionismo e seus reflexos sobre o setor agroexportador brasileiro, destacando o caso da carne bovina. As barreiras comerciais têm dificultado a apropriação de ganhos de comércio pelas economias agroexportadoras. Para verificar os reflexos desse comportamento protecionista, analisou-se as exportações brasileiras de carne bovina para três importantes compradores (União Europeia, Rússia e Irã), de modo a também destacar suas respectivas peculiaridades. Os três casos examinados demonstraram as dificuldades que o Brasil tem para se ajustar às diferentes e voláteis exigências desses mercados. A adequação às exigências se tornou a melhor resposta a um sistema cada vez mais competitivo e dinâmico. Ademais, as "novas" práticas protecionistas são de difícil regulação, pois se confundem com a soberania das nações e com suas características econômicas, políticas e culturais.

Palavras-chave: barreiras não-tarifárias; carne bovina; exportações; comércio agrícola; novo protecionismo

\footnotetext{
Abstract: Brazil is the second largest producer of beef in the world and has been the leader in the international ranking of these exports since 2008. Alongside other developing countries, Brazilian exports of agricultural products have been affected from competitive practices based on non-tariff barriers. The goalof this article is to discuss the impacts of the new protectionism on the Brazilian agro-export sector, highlighting the case of beef exports. Trade barriers have hindered the appropriation of trade gains by agro-exporting economies. In order to verify the impact of this protectionist behavior, we analyzed Brazilian beef exports to three important
} 
VALE, Andressa Ramos Vieira; PEREIRA, Wellington. Disputas e Barreiras NãoTarifárias no Comércio Agrícola: as exportações de carne bovina brasileira entre 2006 e 2015.

partners, in order to highlight their respective peculiarities: European Union, Russia and Iran. All cases examined demonstrated difficulties that Brazil has in adjusting itself to the different and volatile requirements of these markets. Compliance with requirements has become the best response to an increasingly competitive and dynamic system. In addition to that, the "new" protectionist practices are difficult to be regulated, as they are misunderstood as being part of the nations' sovereignty and part of their economic, political and cultural characteristics.

Keywords: non-tariff barriers; beef exports; agricultural trade; new protectionism.

\section{Introdução}

O comércio internacional se tornou um dos fatores mais importantes para flutuação da atividade econômica mundial. A expansão da fronteira de possibilidades econômicas, produtivas e comerciais possibilitada pelas trocas comerciais vem moldando a economia mundial de maneira irreversível. A liberalização comercial vem sendo perseguida como ideal para justiça econômica e social, e justificada pelos ganhos comparativos e custos de oportunidades. Porém, a heterogeneidade do desenvolvimento econômico e social das nações faz questionar se a total liberalização comercial é o caminho ideal, principalmente porque costuma ser injusta com as economias menos desenvolvidas. Ademais, as bases da defesa do livre comércio são questionáveis. Além do histórico nacionalista das grandes potências econômicas, suas práticas protecionistas atuais vêm fazendo com que países em desenvolvimento sofram com concorrências predatórias, delegando-lhes a produção e a comercialização de produtos do setor primário.

Não obstante as dificuldades no âmbito do comércio internacional do setor industrial dos países em desenvolvimento, as práticas protecionistas dos países desenvolvidos em relação ao setor agropecuário geram grandes impasses nas negociações da Organização Mundial do Comércio (OMC). De um lado estão os países subdesenvolvidos cujas economias dependem do setor agropecuário, e do outro os países desenvolvidos, cuja sobrevivência do setor agropecuário depende do apoio estatal. Atualmente, as práticas protecionistas têm se resumido essencialmente às barreiras não-tarifárias, definidas como qualquer restrição, despesa ou

Revista Brasileira de Políticas Públicas e Internacionais, v.3, n.2, Dezembro/2018, pp. 01-28. 
VALE, Andressa Ramos Vieira; PEREIRA, Wellington. Disputas e Barreiras NãoTarifárias no Comércio Agrícola: as exportações de carne bovina brasileira entre 2006 e 2015.

política que não seja uma tarifa e que limite o acesso de produtos importados, como quotas, sistemas de licenciamento, regulamentos sanitários e proibições.

O Brasil se insere na gama de países em desenvolvimento que são dependentes do setor primário agroexportador. Devido à grande disponibilidade de terras, ao clima favorável, à mãode-obra não qualificada e aos avanços tecnológicos para o cultivo de diversas culturas agrícolas, a agropecuária se tornou um dos pilares de sustentação das exportações brasileiras. O Brasil é o segundo maior produtor de carne bovina do mundo e lidera o ranking internacional de exportações desde 2008. Além disso, é o maior produtor e exportador de café, açúcar, etanol, soja e suco de laranja, o terceiro maior exportador de algodão e o terceiro maior produtor e exportador de milho (MAPA, s/d).

Pautando-se nesse contexto, o objetivo deste artigo é compreender as características do “novo protecionismo” (uso de barreiras não-tarifárias) e discutir os seus impactos sobre o setor agroexportador brasileiro, destacadamente no que tange ao caso da carne bovina. Assim, questiona-se quais e como têm sido as implicações para os fluxos comerciais do Brasil para países parceiros que têm adotado medidas protecionistas em âmbito administrativo e fitossanitário, no contexto do "novo protecionismo".

Segundo Krugman e Obstfeld (2010), as barreiras comerciais vão contra os preceitos teóricos do livre comércio, dificultando a apropriação de ganhos de comércio para as economias agroexportadoras e contribuindo para elevar os preços ao consumidor final. Neste sentido, este artigo apresenta os fluxos comerciais e discute as ações protecionistas sobre as vendas brasileiras de carne bovina a três parceiros estratégicos: União Europeia, Rússia e Irã. A importância desses mercados se deve ao seu expressivo volume de compras de carnes brasileiras no período examinado e ao fato de que cada um deles permite a compreensão de diferentes peculiaridades (inclusive culturais) no comércio internacional de proteína animal. A pesquisa foi realizada se utilizando tanto da abordagem qualitativa (revisão bibliográfica, análise documental primária e secundária, análise de questões jurídicas e levantamento de informações em veículos da imprensa especializada) e quantitativa (por meio da análise de estatísticas comerciais descritivas).

Revista Brasileira de Políticas Públicas e Internacionais, v.3, n.2, Dezembro/2018, pp. 01-28. 
VALE, Andressa Ramos Vieira; PEREIRA, Wellington. Disputas e Barreiras NãoTarifárias no Comércio Agrícola: as exportações de carne bovina brasileira entre 2006 e 2015.

A busca pela liberalização não é simples e gera conflitos de interesses legítimos. Com esses três exemplos foi possível discutir suas peculiaridades no comércio de carne bovina com o Brasil e demonstrar como as barreiras comerciais podem assumir diversas facetas de modo a atender interesses diferenciados. A análise reforçou a dificuldade em se diferenciar as barreiras administrativas comerciais (não-tarifárias) impostas com o objetivo de dificultar o comércio daquelas que são utilizadas com vistas a resguardar e defender a soberania das nações e os interesses de sua população.

Além dessa introdução, o artigo possui outras três seções. A segunda seção apresenta a discussão teórica e histórica sobre a regulação do comércio internacional desde a criação do GATT em 1947 e as características e modus operandi do “novo protecionismo” (por meio das barreiras não-tarifárias). A terceira seção apresenta a análise empírica dos fluxos comerciais de exportação de carne bovina brasileira para os três parceiros selecionados para o estudo: União Europeia, Rússia e Irã. Por fim, a quarta seção apresenta os comentários finais e conclusões.

\section{A regulação do comércio internacional}

O GATT, Acordo Geral Sobre Tarifas e Comércio, foi assinado em 1947 com a finalidade de solucionar conflitos de comércio e estreitar as relações comerciais no pósSegunda Guerra Mundial. Desde então, já se passaram oito rodadas de negociações (excetuando-se a rodada de Doha, lançada em 2001, e que ainda não foi efetivamente concluída). Nas primeiras rodadas, ocorridas entre 1947 e 1961, as reduções tarifárias foram o tema central das discussões. Somente a partir da $6^{\text {a }}$ rodada, intitulada como rodada Kennedy (1964-1967), foram incluídas questões relacionadas às barreiras comerciais não-tarifárias e problemas referentes ao comércio de produtos agrícolas (Gonçalves, Silva e Simões, 2006). Mas foi somente durante a $8^{\mathrm{a}}$ rodada (iniciada em 1986 em Punta del Este, no Uruguai, e finalizada em 1994), que se obtiveram os maiores avanços na orientação de ações voltadas ao livre comércio, especialmente de produtos agrícolas (Rego, 1996).A partir dessa rodada, a agricultura foi inserida às normas do GATT, de modo que os países deveriam aceitar, principalmente, a redução dos subsídios e do apoio doméstico aos produtores locais, tal como a

Revista Brasileira de Políticas Públicas e Internacionais, v.3, n.2, Dezembro/2018, pp. 01-28. 
VALE, Andressa Ramos Vieira; PEREIRA, Wellington. Disputas e Barreiras NãoTarifárias no Comércio Agrícola: as exportações de carne bovina brasileira entre 2006 e 2015.

redução de todas as tarifas (Thorstensen, 2001).A própria Organização Mundial do Comércio (OMC) foi aprovada no âmbito da rodada do Uruguai, e efetivamente criada em 1994. A OMC substituiu o GATT, que somente era um acordo, e passou a ter um papel institucional no gerenciamento das regras do comércio internacional.

Após a rodada do Uruguai, houve um aumento no "gap” econômico entre os países desenvolvidos e os em desenvolvimento, pois, a rodada estabeleceu obrigações ambiciosas nos campos de interesse dos países industrializados e, em contrapartida, estabeleceu acordos muito tímidos nas áreas de interesse dos países em desenvolvimento (Rodrigues e Paula, 2008). Os países agroexportadores iniciaram, em 2001, a rodada de Doha com grandes expectativas para o setor, o que tem sido o grande impasse para o seu efetivo fim. Ademais, os países desenvolvidos comercializam, em sua maioria, por meio de acordos preferenciais e aplicam, crescentemente, subsídios agrícolas. Contudo, em dezembro de 2015, durante a décima conferência ministerial da OMC, realizada na capital do Quênia, obteve-se um importante resultado para o agronegócio, ao eliminar imediatamente os subsídios à exportação de produtos agrícolas por parte dos países desenvolvidos, e colocar um prazo até 2018 para que as nações em desenvolvimento se adaptassem e acabassem com seus subsídios às exportações (Galvão, Abreu e Pimentel, 2015). Cabe registrar que os subsídios agrícolas provocam queda nos preços internacionais e causam perdas extraordinárias para os países que dependem da produção agrícola. Os países desenvolvidos utilizam bem mais subsídios do que os países em desenvolvimento devido à elevada necessidade de capital para este tipo de política pública (Silva, Triches e Malafaia, 2011).

O princípio básico que norteia a teoria clássica do comércio internacional considera que os países devem utilizar seus recursos nos segmentos produtivos onde sejam obtidos os maiores níveis de produtividade. Isso contribuiria para aumentar a especialização relativa e a renda em todos os países, de modo que possam explorar suas verdadeiras vantagens comparativas (Krugman e Obstfeld, 2010; Silva, Triches e Malafaia, 2011). Contudo, visto que as vantagens comparativas das economias em desenvolvimento estão, majoritariamente, na comercialização do setor primário e que este setor é fortemente protegido nas economias desenvolvidas, o

Revista Brasileira de Políticas Públicas e Internacionais, v.3, n.2, Dezembro/2018, pp. 01-28. 
VALE, Andressa Ramos Vieira; PEREIRA, Wellington. Disputas e Barreiras NãoTarifárias no Comércio Agrícola: as exportações de carne bovina brasileira entre 2006 e 2015.

gargalo e as desigualdades no comércio entre as nações só aumentaram. Assim, a necessidade protecionista dos países em desenvolvimento em resposta às ações dos países mais desenvolvidos gerou um círculo vicioso, ampliando um impasse crucial à liberalização comercial.

Desde o fim da Segunda Guerra Mundial as negociações para a liberalização do comércio internacional evoluíram amplamente, mas novos impasses têm surgido. As rodadas de negociações conseguiram reduzir as barreiras tarifárias ao comércio. Contudo, essa “conquista” veio acompanhada de um novo obstáculo ao fluxo de comércio internacional, conhecido como "novo protecionismo".

\subsection{Novo protecionismo}

O “novo protecionismo” são os mecanismos adotados pelos países desenvolvidos para burlar e/ou dificultar a liberalização comercial relacionada aos direitos aduaneiros de países em desenvolvimento quando exportam seus produtos agrícolas. Esse termo foi criado na década de 1970 para caracterizar a mudança de postura dos países que passaram a não privilegiar o protecionismo por meio das tarifas, mas sim por meio de regulamentos técnicos, sanitários e fitossanitários como forma de dificultar a entrada de produtos importados. Assim, outras formas mais “sutis” de protecionismo (as barreiras não-tarifárias) passaram a fazer parte do cotidiano das relações comerciais (Lelis e Amaral, 2012).

As tarifas extracotas, as medidas de salvaguarda, os direitos antidumping e os direitos compensatórios também têm sido medidas adotados por muitos países não apenas para proteger sua produção interna, mas também como forma de arrecadação extra no contexto do que tem sido chamado de "novo protecionismo". Questões como a preocupação da sociedade com a segurança, qualidade dos produtos e com o meio ambiente fazem surgir muitas normas, padrões e requisitos de produção, os quais acabam se tornando barreiras ao fluxo de mercadorias. $\mathrm{Na}$ tentativa de encontrar o equilíbrio entre a proteção dos interesses nacionais e com a “obrigação” de não criar obstáculos ao comércio internacional, os países têm se utilizado das barreiras não-tarifárias com mais frequência (Lelis e Amaral, 2012). Assim, ao longo dos anos,

Revista Brasileira de Políticas Públicas e Internacionais, v.3, n.2, Dezembro/2018, pp. 01-28. 
VALE, Andressa Ramos Vieira; PEREIRA, Wellington. Disputas e Barreiras NãoTarifárias no Comércio Agrícola: as exportações de carne bovina brasileira entre 2006 e 2015.

estas ações caracterizadas no âmbito do "novo protecionismo" têm conseguido manter a proteção a produtores ineficientes dentro dos países desenvolvidos, destacadamente na Europa no que tange aos segmentos agrícolas, e tem gerado claros obstáculos ao comércio internacional.

Segundo Lamy (2014), o custo das restrições administrativas é atualmente duas vezes maior que o custo dos direitos aduaneiros. Porém, essas práticas protecionistas retornam à condição de deslealdade comercial tão discutida nas rodadas de negociações desde a criação do GATT. Os países em desvantagem têm apertado seus orçamentos para tentar fazer frente à concorrência desleal, porém, sem jamais conseguirem atingir o patamar adequado, ao mesmo tempo em que geram mais desequilíbrios em suas economias internas (Lima-Campos, 2015). Essas medidas visam a proteção dos interesses sanitários, econômicos, e podem, inclusive,advir de uma política pública para restrição de algum tipo de produto considerado nocivo. O problema surge quando tais direitos soberanos de um Estado acabam se tornando pretexto para, de certa maneira, burlar as normas de livre comércio da OMC de forma arbitrária e seletiva. Miranda (2001) ressalta a dificuldade da comprovação de algumas barreiras não tarifárias ao comércio, as quais têm se tornado bastante complexas. Algumas delas podem ser mais evidentes como é o caso de barreiras sanitárias, mas outras podem ser menos “visíveis” quando envolvem medidas político-administrativa.

Um exemplo de práticas administrativas protecionistas são as barreiras não-tarifárias, algumas delas reguladas a nível global, enquanto outras advêm de acordos multilaterais ou bilaterais, visando objetivos sociais, ecológicos, sanitários e de segurança. São inúmeras as medidas possíveis de proteção adotadas pelos países em prol de seu mercado interno. Como discorrem Contini e Talamini (2005), a União Europeia, que é um dos maiores parceiros comerciais do Brasil, impõe diversas tarifas sazonais em função de seu nível de produção agrícola e medidas de apoio ao produtor europeu: subsídios à produção e isenção de tarifação dentro de todo território europeu e restrições fitossanitárias minuciosas às importações.

Existem inúmeras maneiras de se dificultar a entrada de produtos em um país por meio de diversas burocracias criadas para tal finalidade. As barreiras não-tarifárias passaram a

Revista Brasileira de Políticas Públicas e Internacionais, v.3, n.2, Dezembro/2018, pp. 01-28. 
VALE, Andressa Ramos Vieira; PEREIRA, Wellington. Disputas e Barreiras NãoTarifárias no Comércio Agrícola: as exportações de carne bovina brasileira entre 2006 e 2015.

representar 70\% das barreiras comerciais, e após a crise de 2008 elas têm se intensificado como justificativa para a manutenção do emprego e do nível de produção das indústrias internas (Lelis e Amaral, 2012). Essa dicotomia se prolongou com o passar dos anos, o que tem dificultado o fechamento da Rodada de Doha, na qual é defrontando um posicionamento mais incisivo dos países em desenvolvimento perante os países europeus no âmbito do G20.

A aplicação das barreiras administrativas também têm sido objeto de questionamento nos tribunais internacionais junto à OMC. A finalidade dos tribunais é tornar o comércio internacional mais justo respeitando a soberania das nações e as regras acordadas junto à OMC. A criação da OMC e a regulamentação do comércio internacional possibilitou, através do interesse mútuo das nações, a resolução de conflitos comerciais de maneira pacífica. Apesar da enorme força dos países industrializados na defesa do livre comércio de produtos manufaturados na OMC, a defesa dos interesses das nações exportadoras de produtos agrícolas também começou a ganhar mais espaço. Como já registrado, o "novo protecionismo” confunde a defesa da soberania e dos interesses do bem-estar nacional com embargos ao livre comércio. Ele prejudica fortemente os países em desenvolvimento exportadores de produtos agrícolas e cria maior dificuldade em se lidar e regulamentar essas práticas.

O Brasil é o país em desenvolvimento mais atuante no âmbito da OMC no que concerne à solução de controvérsias na liberalização do comércio internacional, visto que em números, está atrás apenas dos Estados Unidos, da União Europeia e do Canadá (Andrade, 2010) ${ }^{1}$. As contestações brasileiras são massivamente no campo da agricultura, principal fonte de rendas do comércio internacional dos países em desenvolvimento. Como Barral e Amaral (2015) ressaltam, contestar incentivos agrícolas no âmbito da OMC não é uma tarefa simples, e exige demonstração do subsídio e caracterização do dano gerado à economia doméstica, informações que para serem levantadas necessitam de recursos elevados e pessoal especializado. A maioria das disputas comerciais levadas até ao Órgão de Solução de Controvérsias(OSC) da OMC são

\footnotetext{
${ }^{1}$ Informações disponibilizadas pela OMC em seu website mostram que até março/2018 o Brasil é o quarto país em número de autorias de queixas registradas (31 casos) contra outros países. Na frente estão EUA (115 casos), União Europeia (97 casos), Canadá (38 casos). Já o México (24 casos), Índia (23 casos), Japão (23 casos), Coreia do Sul (18 casos) e China (15 casos) aparecem após o Brasil. Informações disponíveis em: https://www.wto.org/english/tratop_e/dispu_e/dispu_by_country_e.htm. Consultado em 28/02/2018.
}

Revista Brasileira de Políticas Públicas e Internacionais, v.3, n.2, Dezembro/2018, pp. 01-28. 
VALE, Andressa Ramos Vieira; PEREIRA, Wellington. Disputas e Barreiras NãoTarifárias no Comércio Agrícola: as exportações de carne bovina brasileira entre 2006 e 2015.

do setor agrícola, dado que a proteção governamental ao setor agrícola se mantém ainda muito elevada. Um dado interessante é que os países desenvolvidos dominam o mercado mundial de produtos agrícolas, apesar das vantagens comparativas dos países subdesenvolvidos (Bruno, Azevedo e Massuqueti, 2012).

Segundo Nassar, Bachion e Zambianco (2014),a maior parte do apoio doméstico concedido pela UE e pelos EUA é dirigida aos grandes produtores agrícolas. Como os subsídios são condicionados ao nível de produção, os maiores produtores e aqueles mais eficientes são os principais beneficiários. A UE e os EUA são os líderes mundiais na concessão de subsídios, gerando distorção nos níveis de preços no mercado agrícola mundial. Por consequência, são também as nações que mais sofrem retaliações por parte da OMC (Bruno, Azevedo e Massuqueti, 2014). O fato de os EUA também ser um grande exportador de commodities agrícolas faz com que ele também compita diretamente com o Brasil no comércio internacional agrícola. As principais disputas estão na comercialização da soja, do milho e do algodão, razão pela qual o país está sempre atento às políticas norte-americanas (Nassar, Bachion e Zambianco, 2014).

As práticas protecionistas, principalmente aquelas que se utilizam de subsídios, premiam as ineficiências, distorcem os preços de mercado, absorvem os ganhos de eficiência e qualidade que seriam obtidos por meio da competitividade, e oneram pesadamente os governos e os contribuintes (Sbarai e Miranda, 2014). Porém, em respeito à soberania do país, a OMC ainda não tem real poder para acabar com essas práticas. A solução observada para os contenciosos são compensações financeiras que ajudam a mitigar os danos causados, mas não são capazes de resolver todos os desencadeamentos gerados por tais práticas.

\subsubsection{Barreiras sanitárias e fitossanitárias}

As medidas sanitárias e fitossanitárias são para proteção da saúde das pessoas, animais ou plantas de um determinado país contra ameaças biológicas externas. Essas medidas incluem

Revista Brasileira de Políticas Públicas e Internacionais, v.3, n.2, Dezembro/2018, pp. 01-28. 
VALE, Andressa Ramos Vieira; PEREIRA, Wellington. Disputas e Barreiras NãoTarifárias no Comércio Agrícola: as exportações de carne bovina brasileira entre 2006 e 2015.

leis, decretos, regulamentos, requerimentos e procedimentos que definem critérios para produtos, processos e métodos de produção. Enquanto as medidas sanitárias visam a proteção de pessoas e animais, as fitossanitárias visam a proteção de plantas e frutas perante doenças e pestes.

Durante a rodada de negociações do Uruguai foi assinado o Acordo sobre Aplicação de Medidas Sanitárias e Fitossanitárias (Acordo SPS), o qual regula a aplicação destes temas no comércio multilateral. O acordo legitima exceções ao livre comércio, as quais podem ser utilizadas pelos membros da OMC quando houver necessidade de proteger a vida e a saúde, porém, sem que os países utilizem desse artifício para criar barreiras ao livre comércio.

O Brasil tem constantes problemas com aplicação de restrições sanitárias por parte de vários países como os da União Europeia, por exemplo. Por essa mesma razão o Brasil já sofreu sanções da Rússia, e sofre até hoje de países da América do Norte, especificamente os que compõem o NAFTA que negam acesso da carne bovina brasileira aos seus mercados.

O Brasil está dentro da área livre de doenças ou pragas, reconhecido pelo acordo sobre aplicação de medidas sanitárias da OMC, conhecido como princípio da regionalização, princípio pelo qual um país é considerado com as demais regiões de seu território livres de uma determinada doença por mais que a mesma tenha ocorrido em um local específico. Porém, vários países signatários não reconhecem esse acordo como, por exemplo, Estados Unidos, Canadá, Nova Zelândia, Tailândia, Austrália e o Japão. Não se sabe até que ponto esses países estão sobre utilizando o artifício fitossanitário para dificultar a inserção da carne bovina brasileira em seus mercados, pois, coincidência ou não, dentre eles estão quatro dos maiores produtores de carne bovina do mundo (International Beef Alliance, s/d).

Mas, sabe-se também que o Brasil precisa recuperar sua credibilidade no quesito da sanidade animal perante o mercado internacional, pois com procedimentos sanitários comprovadamente confiáveis não há meios de sofrer restrições comerciais internacionais sem que os outros países descumpram as regras estabelecidas e por eles assinadas no âmbito da OMC. Ademais, o Brasil precisa melhorar sua cadeia produtiva para superar as barreiras técnicas produtivas e sanitárias, pois o país não possui um sistema de rastreabilidade e

Revista Brasileira de Políticas Públicas e Internacionais, v.3, n.2, Dezembro/2018, pp. 01-28. 
VALE, Andressa Ramos Vieira; PEREIRA, Wellington. Disputas e Barreiras NãoTarifárias no Comércio Agrícola: as exportações de carne bovina brasileira entre 2006 e 2015.

certificação confiável, o que dificulta a abertura e/ou ampliação dos mercados (Silva, Triches e Malafaia, 2011). Somam-se a isso as falhas recorrentes no SISBOV (Serviço Brasileiro de Rastreabilidade da Cadeia Produtiva de Bovinos e Bubalinos, instituído em 2006) que acarretam sempre restrições por parte de países importadores. Florindo, Medeiros e Mauad (2015) ressaltam a importância da rastreabilidade não só porque ela é utilizada como uma forma de barreira não tarifária, mas porque também, garante a segurança sanitária do animal e a qualidade do produto final, dando maior transparência e elevando a visibilidade do produto no mercado internacional.

A complexidade das barreiras administrativas influencia o fluxo de comercialização da carne bovina nacional, por isso a importância da discussão referente às formas de proteção abrangidas pelo “novo protecionismo”. De modo a analisar os reflexos dessas barreiras nãotarifárias ao setor agroexportador brasileiro, apresentar-se-á o perfil do comércio internacional de carne bovina com três importantes parceiros, cada qual representando diferentes peculiaridades na relação de comércio. Apesar de o Brasil estar entre os líderes na produção e comercialização de carne bovina, o setor demonstra certa debilidade no comércio internacional no que tange à sua dependência da maleabilidade das barreiras comerciais das nações importadoras.Será possível compreender que mesmo um setor exportador caracterizado como competitivo internacionalmente também fica à mercê de práticas protecionistas.

\section{O comércio internacional de carne bovina brasileira}

A produção de carne bovina brasileira movimenta cerca de R \$ 167,5 bilhões por ano e gera mais de 7 milhões de empregos. Estima-se que 20\% da área do território nacional é ocupada por pastagens. O Brasil, atualmente, oscila entre segundo e terceiro maior produtor de carne bovina do mundo, e pode ultrapassar os EUA nos próximos cinco anos (ABIEC, s/d).

O panorama das exportações brasileiras de carne bovina pode ser observado na Figura 1 mostra as exportações entre 2006 e 2015 de carne in natura, carnes industrializadas, miúdos, tripas e carnes salgadas.

Revista Brasileira de Políticas Públicas e Internacionais, v.3, n.2, Dezembro/2018, pp. 01-28. 
VALE, Andressa Ramos Vieira; PEREIRA, Wellington. Disputas e Barreiras NãoTarifárias no Comércio Agrícola: as exportações de carne bovina brasileira entre 2006 e 2015.

Figura 1- Exportações de carne bovina brasileira entre 2006 e 2015 (US\$ bilhões e em mil tons)

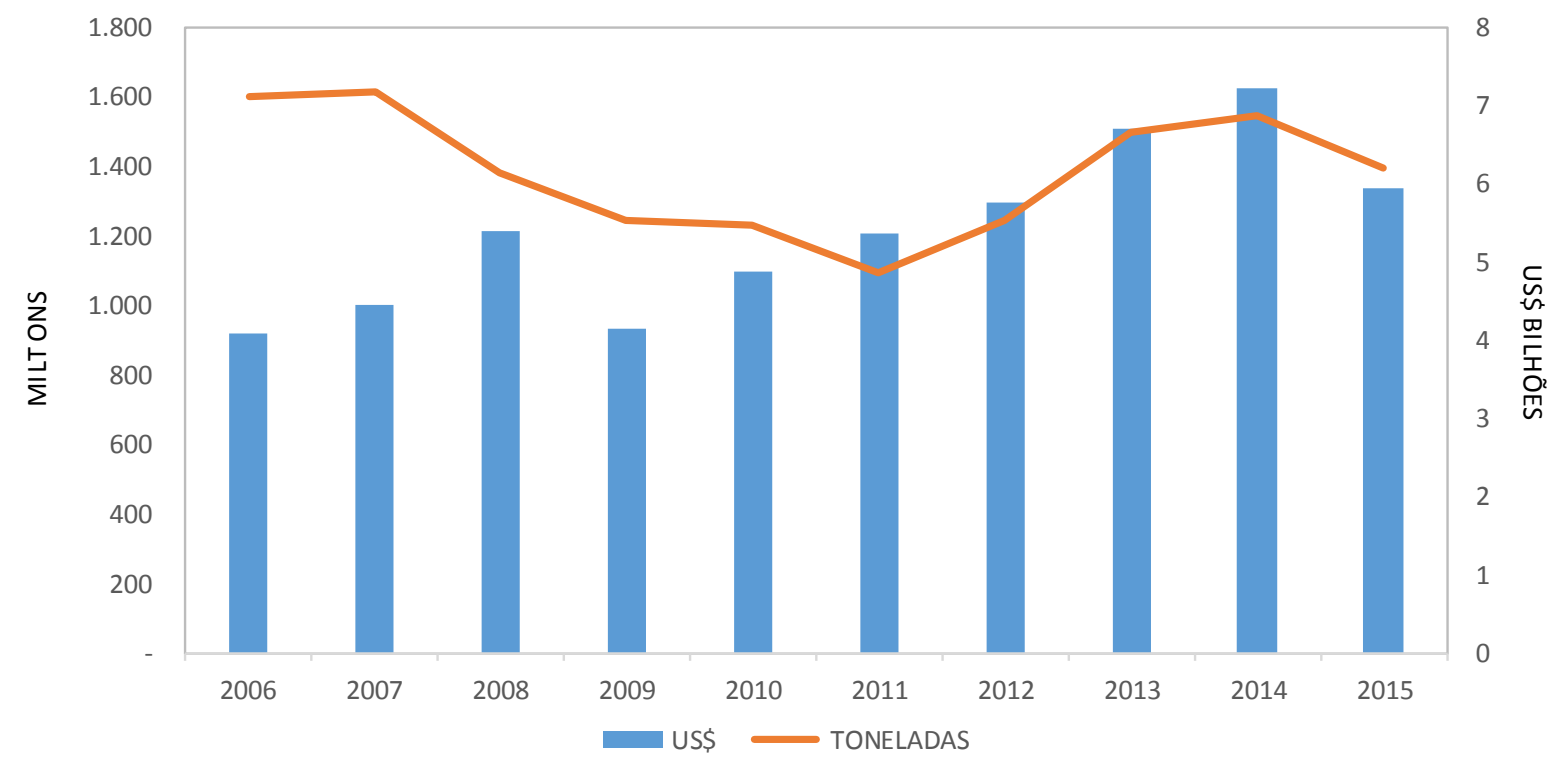

FONTE: Elaboração própria a partir de dados disponibilizados no website da ABIEC.

Percebe-se que o ápice das exportações ocorre em 2007, com 1,62 milhões de toneladas de carne bovina. Um dos motivos da queda em 2008 foi a crise internacional que, de acordo com Paula e Ferrari Filho (2011), reduziu a demanda internacional por esses produtos. Outro motivo foi o embargo da União Europeia, maior importador de carne bovina brasileira, a vários produtores no ano em questão. As quedas nas exportações se prolongaram até 2011, voltando a crescer a partir de 2012.

Na sequência, a Figura 2 mostra os 8principais países importadores da carne bovina brasileira, mais a União Europeia (UE). Entre 2006 e 2013, a Rússia era o principal importador, quando foi ultrapassada por Hong Kong. De 2014 para 2015 houve uma redução significativa das vendas brasileiras para a Rússia devido à crise naquele país agravada pela queda no preço do petróleo e pela desvalorização de sua moeda. Já Hong Kong passou a ser um grande

Revista Brasileira de Políticas Públicas e Internacionais, v.3, n.2, Dezembro/2018, pp. 01-28. 
VALE, Andressa Ramos Vieira; PEREIRA, Wellington. Disputas e Barreiras NãoTarifárias no Comércio Agrícola: as exportações de carne bovina brasileira entre 2006 e 2015.

destaque devido ser a porta de entrada para a carne consumida na China, país que impôs diversas barreiras sanitárias às importações de carne bovina brasileira. Contudo, a partir de 2015 já se verifica um forte crescimento das compras diretas da carne brasileira pela China. A aproximação da China com o Ocidente devido a sua maior abertura econômica nos últimos anos é um dos motivos do aumento do consumo da carne bovina. A crescente classe média chinesa tem sido um forte demandante de carne vermelha (Thukral e Patton, 2014). Já as exportações para o Egito tiveram queda em 2011, mas em 2015 voltaram a crescer, superando, sazonalmente, a Rússia. Os países apontados na Figura 2 foram selecionados por serem os maiores importadores no ano de 2015.

Figura 2 - Principais países importadores da carne bovina brasileira em 2006 e 2015 (mil tons)

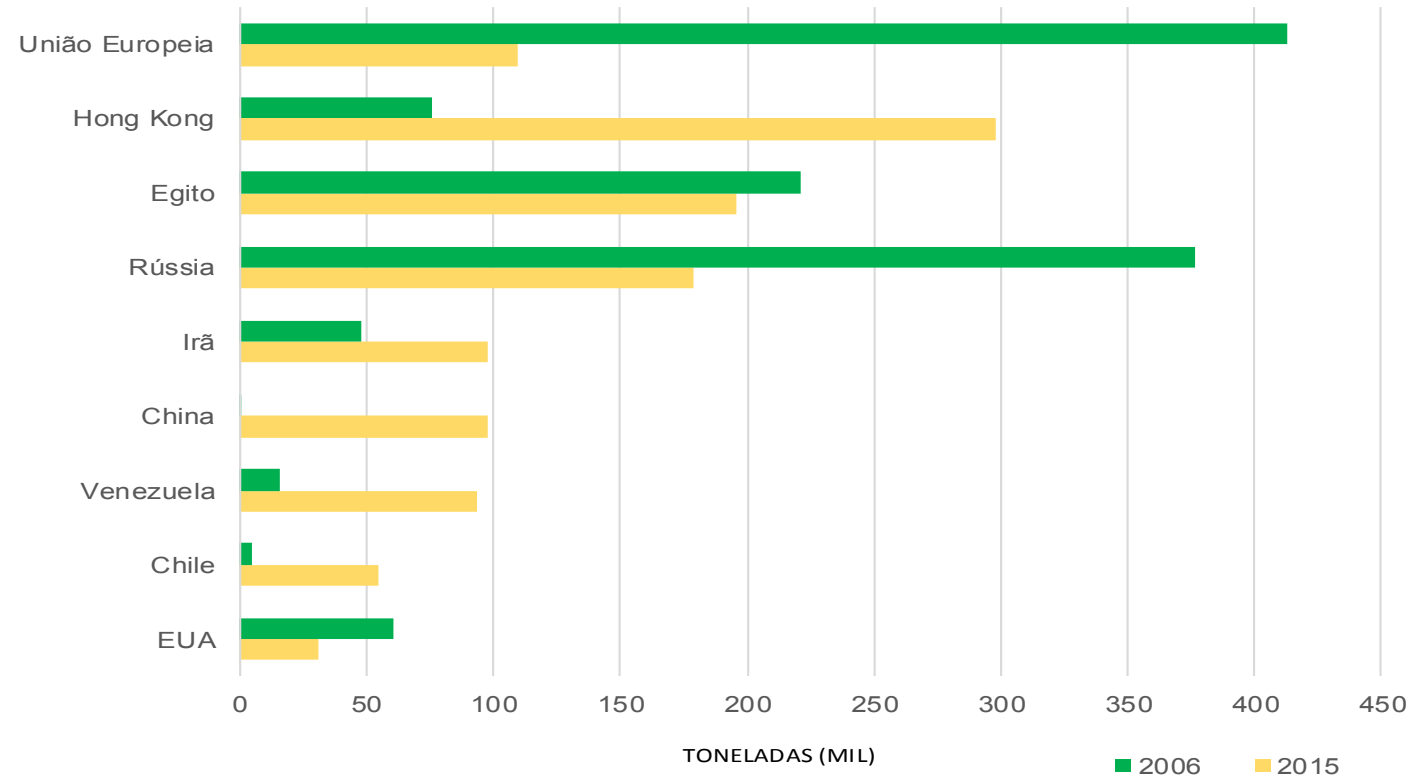

FONTE: Elaboração própria a partir de dados disponibilizados no website da ABIEC.

Os países da União Europeia (UE) foram adicionados como um bloco econômico na Figura 2 porque são um importante parceiro comercial do Brasil e tem bastante expressividade na importação da carne bovina brasileira. A principal barreira comercial que hoje dificulta uma maior quantidade de comercialização de carne com a EU são as barreiras sanitárias. A

Revista Brasileira de Políticas Públicas e Internacionais, v.3, n.2, Dezembro/2018, pp. 01-28. 
VALE, Andressa Ramos Vieira; PEREIRA, Wellington. Disputas e Barreiras NãoTarifárias no Comércio Agrícola: as exportações de carne bovina brasileira entre 2006 e 2015.

complexidade destas barreiras está na linha tênue entre um entrave ao comércio internacional e a defesa dos interesses sanitários nacionais. Outro importante aspecto econômico da UE está na quantidade de subsídios distribuídos aos seus produtores ineficientes. Esses aspectos referentes serão discutidos no próximo subitem, juntamente com a dinâmica das exportações de carne bovina para a Rússia e o Irã. De um lado, a Rússia possui papel relevante no comércio deste segmento pois é um dos grandes países importadores da carne brasileira e suas posições políticas e econômicas perante o mundo influenciam demasiadamente seus parceiros comerciais. Uma maior aproximação com a América Latina, em oposição a uma diminuição das trocas comerciais com gigantes econômicos como a União Europeia e os Estados Unidos, reserva à Rússia um papel de destaque nas trocas comerciais com o Brasil, principalmente no setor agropecuário. Por outro lado, o Irã foi selecionado por ser um dos principais importadores da carne brasileira e por apresentar dificuldades políticas no relacionamento comercial com outras grandes economias agroexportadoras. Isso propiciou uma maior aproximação a países como o Brasil, o qual se adaptou a exigências impostas devidos a costumes culturais e religiosos no que se refere ao preparo e envio de alimentos importados por países com população predominantemente muçulmana, como é o caso do Irã. A adequação do abate e corte da carne bovina segundo os preceitos islâmicos demonstra que ao invés dessa exigência ser uma barreira comercial, ela oportunizou uma vantagem comercial para os frigoríficos brasileiros. O comércio brasileiro de carne bovina com esses três parceiros permite ver peculiaridades específicas a cada caso, ao mesmo tempo em que é possível destacar os diferentes entraves comerciais.

\subsection{União Europeia}

Os dados apresentados anteriormente mostram os principais países importadores da carne bovina brasileira. Porém, ao se considerar a União Europeia de forma agregada, vê-se que o bloco é o maior comprador do produto brasileiro. Em contrapartida, a UE é o mercado que mais aplica políticas protecionistas ao setor agropecuário (MRE, 2012a). As duas economias possuem um relacionamento comercial importante. De modo geral, o Brasil é o

Revista Brasileira de Políticas Públicas e Internacionais, v.3, n.2, Dezembro/2018, pp. 01-28. 
VALE, Andressa Ramos Vieira; PEREIRA, Wellington. Disputas e Barreiras NãoTarifárias no Comércio Agrícola: as exportações de carne bovina brasileira entre 2006 e 2015.

principal exportador de commodities agrícolas para a União Europeia. Em 2015 o Brasil exportou 13 bilhões de euros em commodities agrícolas, o que equivaleu a 11,6\% das importações da UE (CE, 2016).

A UE se utiliza da imposição de várias barreiras não-tarifárias, tal como as cotas para o comércio de produtos agrícolas. Umas delas se refere à Cota Hilton que limita a importação de carnes. Essa cota é constituída para cortes especiais do quarto traseiro de novilhos precoces, e seu preço é maior no mercado internacional. A cota atual para a União Europeia é de 65.250 toneladas, e a ela só tem acesso os países credenciados: Argentina, Austrália, Brasil, Uruguai, Nova Zelândia, Estados Unidos da América, Canadá e Paraguai. A cota possui uma taxa de importação de 20\% ad valorem e a tarifa extra-cota é de 12,8\% mais 303,4 euros por cada $100 \mathrm{~kg}$ de carne. A cota brasileira atual é de 10.000 toneladas. Contudo, o Brasil não sofre muito com esse contingenciamento, pois ele nunca conseguiu atingir 100\% da cota. Entre junho de 2015 a junho de 2016 se registrou a primeira vez em que o país conseguiu atingir mais que 90\% da cota de 10.000 toneladas (ABIEC, s/d).

Uma das justificativas para o não alcance da cota pelos produtores brasileiros é o excessivo rigor sanitário e técnico que a exportação nessa categoria exige. De acordo com a ABIEC (s/d), os produtores nacionais só conseguiram atingir essa quantidade entre 2015/2016 porque a diferença nos preços compensou os altos custos dessa produção.

Revista Brasileira de Políticas Públicas e Internacionais, v.3, n.2, Dezembro/2018, pp. 01-28. 
VALE, Andressa Ramos Vieira; PEREIRA, Wellington. Disputas e Barreiras NãoTarifárias no Comércio Agrícola: as exportações de carne bovina brasileira entre 2006 e 2015.

Figura 3 - Exportações de carne bovina brasileira para a União Europeia entre 2006 e 2015 (US\$ bilhões e em mil tons)

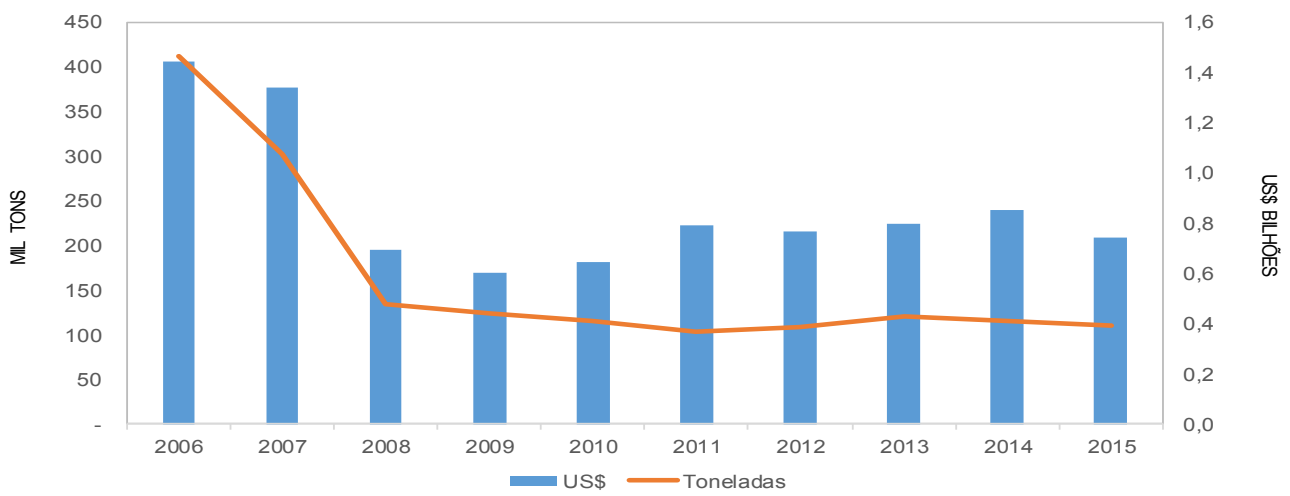

FONTE: Elaboração própria a partir de dados disponibilizados no website da ABIEC.

Ao analisar a Figura 3 fica clara a quebra estrutural no padrão das exportações a partir de 2008. Observa-se, no ano de 2006, o ápice das exportações de carne bovina que ultrapassou as 400 mil toneladas, e em 2008 não atingiu 150 mil toneladas. A variação de 2007 para 2008 foi negativa em 55\%.Já a produção de carne da União Europeia se manteve estável no período de 2004 a 2015, atingindo 8,09 milhões de toneladas em 2008 (FAO, s/d).

Analisando a variação de 2007 para 2008 dos principais exportadores de carne para a União Europeia, nota-se que nenhum deles sofreu queda como visto para o Brasil. Pelo contrário, as exportações de carne bovina norte-americana para a União Europeia aumentaram 75\%, e da Austrália e da Nova Zelândia aumentaram, respectivamente26\% e 18\% (UNCTAD, $\mathrm{s} / \mathrm{d})$.

Não se pode afirmar que houve uma troca da carne bovina brasileira pela carne desses países, pois se compararmos em valores absolutos, enquanto as exportações de carne neozelandesas para a UE chegaram a 1,7 milhões de dólares em 2008, as exportações da carne brasileira para a UE, que estavam em queda, chegaram a cifra de 695,2 milhões de dólares neste ano (UNCTAD, s/d; SECEX, 2016). O ponto central nesta comparação é a conclusão de que a queda das exportações brasileiras para a União Europeia em 2008 é fruto de um embargo apenas ao Brasil. Para que se possa compreender melhor a causa desse embargo, faz-se Revista Brasileira de Políticas Públicas e Internacionais, v.3, n.2, Dezembro/2018, pp. 01-28. 
VALE, Andressa Ramos Vieira; PEREIRA, Wellington. Disputas e Barreiras NãoTarifárias no Comércio Agrícola: as exportações de carne bovina brasileira entre 2006 e 2015.

necessário registrar que a União Europeia passou a adotar rigorosas medidas fitossanitárias. Isso se intensificou porque desde 1995 a UE sofre com casos de doença da "vaca louca" nogado europeu. A doença é uma infecção degenerativa do sistema nervoso central do gado e começou no Reino Unido em decorrência do uso de farinhas feitas a partir de restos de animais na alimentação dos bovinos. Isso provocou uma variante da doença no homem, o que causou dezenas de mortes na Europa (Beefpoint, 2010). Esses acontecimentos deixaram os europeus mais exigentes quanto às medidas sanitárias utilizadas na produção da carne consumida por eles, o que levou a União Europeia a estabelecer um rígido sistema de rastreabilidade do gado e a exigir controle similar dos países exportadores para o bloco (Jornal do Senado, 2008).

A política de segurança dos alimentos da União Europeia se baseia numa abordagem global e integrada ao longo de toda a cadeia alimentar, em todos os setores. A política prevê rastreabilidade dos alimentos do consumo humano e dos animais bem como dos ingredientes utilizados. E em relação às importações a Comissão exige que elas devem satisfazer as condições sanitárias equivalentes às exigidas da produção interna (Contini e Talamini, 2005).O controle de rastreabilidade começou a ser implantado no Brasil no ano de 2000. Neste controle o gado recebe um dispositivo eletrônico que reúne informações sobre sua alimentação e vacinação, do seu nascimento até o abate (Jornal do Senado, 2008).

Em fevereiro de 2008 a União Europeia restringiu o número de fazendas que poderiam receber o certificado para exportação a 300 unidades, ou seja, apenas 3\% das 10 mil cadastradas no Brasil. Porém, o Ministério da Agricultura apresentou uma lista com 2.600 propriedades, o que gerou desconfiança por parte da Comissão. Na época, o comissário europeu de saúde, Markos Kiprianou, declarou que o bloco não poderia ter certeza de que todos os estabelecimentos aprovados pelo Brasil foram inspecionados de maneira adequada e que, por essa razão, suspendeu todas as exportações de carne bovina in natura brasileira para a União Europeia (Nunes e Molina, 2013).

O Brasil começou a se ajustar gradualmente às exigências da União Europeia, e após negociações a lista passou a compreender cerca de 2000 fazendas (Beefpoint, 2010).Quando se analisa os dados gerais de exportação de carne bovina brasileira, nota-se que, apesar da queda

Revista Brasileira de Políticas Públicas e Internacionais, v.3, n.2, Dezembro/2018, pp. 01-28. 
VALE, Andressa Ramos Vieira; PEREIRA, Wellington. Disputas e Barreiras NãoTarifárias no Comércio Agrícola: as exportações de carne bovina brasileira entre 2006 e 2015.

em 2008, o Brasil não sofreu todo o impacto que esse embargo poderia ter causado. Especialistas afirmam que o motivo seria a diversificação dos países importadores da carne bovina nacional, tal como a Rússia, Hong Kong e Egito que absorveram parte da queda das exportações para a União Europeia (ABIEC, s/d).

O paradoxo da política protecionista europeia está no fato de ela ter como finalidade a melhoria da qualidade de vida dos europeus, ao mesmo tempo que aumenta os preços de produtos alimentícios para o consumidor final. De acordo com Sbarai e Miranda (2014), resultados de testes realizados com proxies dos preços internos na UE em relação aos preços internacionais da carne bovina, demonstram que o preço da carne brasileira no mercado europeu é afetado por exigências não tarifárias e impostos de importação. Todas as políticas protecionistas aqui apresentadas tinham como objetivo a manutenção da competitividade do setor, a manutenção de níveis de emprego e de renda, a defesa do meio ambiente e a proteção sanitária das pessoas e animais. Porém, esse tipo de política aumenta os preços para o consumidor interno. Ademais, os subsídios tendem a proteger a ineficiência produtiva, a distribuira renda de maneira ineficaz entre os produtores e a barrar o acesso de países pobres ao desenvolvimento (Contini e Talamini, 2005). Deve-se reconhecer o direito soberano europeu e sua preocupação com fatores sanitários à segurança alimentar, por mais rigorosos que sejam. E cabe ao Brasil se adaptar a essas condições se quiser continuar a prosperar num mercado cada vez mais competitivo e dinâmico.

\subsection{Rússia}

A Rússia é um mercado com 143 milhões de habitantes, é a $12^{\mathrm{a}}$ maior economia do mundo e um dos principais parceiros comerciais do Brasil. No comércio exterior o país ocupa a $14^{\mathrm{a}}$ posição entre os destinos das exportações brasileiras. Em 2011, manteve-se como o principal destino das vendas brasileiras para a Europa Oriental (cerca de 81\% do total exportado para a região) (MRE, 2013).

A União Europeia figurava, tradicionalmente, como o principal parceiro comercial da Rússia até 2013. Em 2014, com as desavenças políticas acerca anexação da região da Criméia à

Revista Brasileira de Políticas Públicas e Internacionais, v.3, n.2, Dezembro/2018, pp. 01-28. 
VALE, Andressa Ramos Vieira; PEREIRA, Wellington. Disputas e Barreiras NãoTarifárias no Comércio Agrícola: as exportações de carne bovina brasileira entre 2006 e 2015.

Rússia, os produtos alimentícios europeus foram embargados e proibidos de serem comercializados no mercado russo, assim como também os norte-americanos, canadenses, australianos e noruegueses (Lossan e Damarcos, 2014). Adicionalmente, em 2012, concluíramse 18 anos de negociações e a Rússia aderiu à OMC. Essa adesão é vista como importante passo rumo à modernização do país, o que poderá trazer vantagens com a integração do tecido produtivo russo às cadeias globais de maior valor agregado. No plano internacional, a adesão tende a conferir maior previsibilidade e segurança jurídica ao processo russo de importação (MRE, 2013).

A composição das exportações brasileiras para a Rússia é majoritariamente de produtos básicos (62\% do total comercializado).Os principais produtos exportados para a Rússia são carnes suína, bovina e de frango, soja e seus derivados, fumo, café, açúcar, amendoim e produtos da extração mineral (SECEX, 2016). Em 2011, mais de 20\% da carne e cerca de 70\% do açúcar importados pela Rússia procederam do Brasil (MRE, 2016). Já as importações brasileiras provenientes da Rússia são majoritariamente (cerca de 65\%) compostas por produtos manufaturados. Os principais produtos importados da Rússia são adubos, borrachas, produtos para a indústria petrolífera e produtos químicos (SECEX, 2016).

Na composição das trocas comercias da Rússia com o Brasil há similaridade com as trocas com a União Europeia. O Brasil importa produtos industrializados e exporta produtos do setor primário produtivo. Isso demonstra, mais uma vez, a característica agroexportadora do Brasil, típica de países em desenvolvimento. A balança comercial brasileira com a Rússia é superavitária entre 2005 e 2015. No período de 2006 a 2012, a diferença das exportações para as importações oscila entre 1,2 e 2,5 bilhões de dólares. A partir de 2012 essa diferença diminuiu, oscilando entre 243,5 mil e 812,7 mil dólares (SECEX, 2016).

As cifras acima relatadas demonstram a importância do mercado russo para o comércio internacional brasileiro de carne bovina. Apesar de ter perdido o posto de maior importador nos últimos anos para Hong Kong, a Rússia ainda é um dos principais importadores e, devido a magnitude do seu mercado, apresenta potencial para um aumento significativo. Ademais, o Brasil goza de benefícios dentro do Sistema Geral de Preferências (SGP), com desconto de

Revista Brasileira de Políticas Públicas e Internacionais, v.3, n.2, Dezembro/2018, pp. 01-28. 
VALE, Andressa Ramos Vieira; PEREIRA, Wellington. Disputas e Barreiras NãoTarifárias no Comércio Agrícola: as exportações de carne bovina brasileira entre 2006 e 2015.

25\% dos direitos aduaneiros em relação às taxas da Tarifa Aduaneira Unificada russa. No geral, os produtos brasileiros são favorecidos, com exceção de alguns embargos temporários que ocorreram às importações de carne (MRE, 2013).

As carnes são os principais produtos brasileiros exportados para a Rússia. Atualmente, 60 unidades produtoras brasileiras estão autorizadas a exportar carne bovina e suína para o mercado russo. No primeiro semestre de 2015, o Brasil se consolidou como líder no mercado russo no comércio de carnes, sendo responsável por 57\% das compras de carne bovina, 82\% da carne suína e 34\% da carne de aves (MAPA, s/d). A Figura 4 mostra as exportações de carne bovina para a Rússia entre 2006 e 2015.

O ápice das exportações da série apresentada se dá em 2007 quando alcança 453,2 mil toneladas exportadas. As sucessivas quedas de 2008, 2009 e 2010 podem ser explicadas pela crise internacional informada anteriormente, e também pelo fato de que em 2009, com o propósito de proteger a produção interna, a Rússia reduziu os limites das quotas para importação de carne bovina e aumentou os impostos para as quantidades que excediam as quotas (MRE, 2013). Em 2011 as exportações caíram 1,5\% em relação a 2010, e o principal fator que explica esse fenômeno é o embargo que a Rússia impôs à importação de carnes provenientes de Mato Grosso, Paraná e Rio Grande do Sul por estarem em desacordo com as especificações sanitárias russas. O embargo durou até o segundo semestre de 2012 (MRE, 2013).

Revista Brasileira de Políticas Públicas e Internacionais, v.3, n.2, Dezembro/2018, pp. 01-28. 
VALE, Andressa Ramos Vieira; PEREIRA, Wellington. Disputas e Barreiras NãoTarifárias no Comércio Agrícola: as exportações de carne bovina brasileira entre 2006 e 2015.

Figura 4 - Exportações de carne bovina brasileira para a Rússia entre 2006 e 2015 (US\$bilhões e em mil tons)

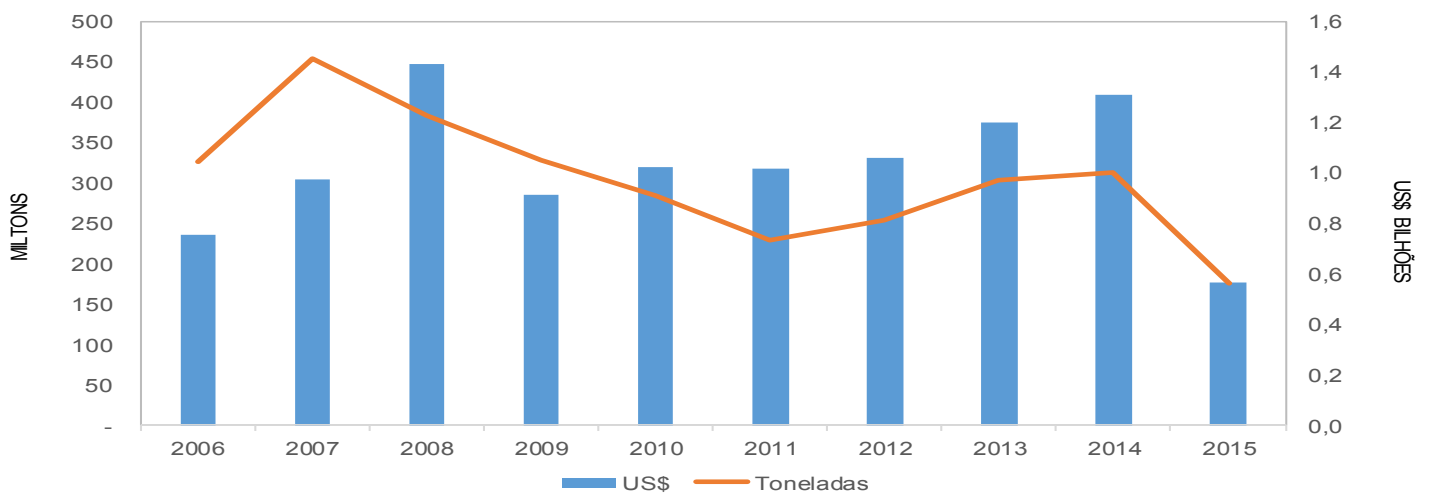

FONTE: Elaboração própria a partir de SECEX (2016).

Em 2014, dois fatores contribuíram para o aumento das exportações. O primeiro foi o embargo russo à inserção de produtos alimentares da União Europeia, Estados Unidos e Canadá em razão da crise política gerada pela tentativa de anexação da região da Criméia. Outra razão foi a suspensão completa das importações de carne bovina australianas devido à identificação de estimulador de crescimento na carne (Kuzmin, 2014). As questões sanitárias têm sido as principais causas de instabilidade das exportações brasileiras de carne bovina. Porém, a importância de uma cadeia produtiva segura e rastreável para a manutenção das trocas comerciais, vai além dessas questões (Florindo, Medeiros e Mauad, 2015).

Devido aos desdobramentos políticos da Rússia com o resto do mundo, ela tem se aproximado muito mais da América Latina para transações comerciais, e o Brasil tem se aproveitado das vantagens dessa política. O exemplo Russo demonstra a magnitude e a dinâmica das barreiras administrativas nos fluxos de comércio internacional.

\section{3. $\operatorname{Ir} \tilde{a}$}

No que concerne ao comércio internacional de carne bovina, o Irã possui exigências muito mais culturais e religiosas do que econômicas e políticas. Assim, as exportações de carne bovina brasileiras para o Irã podem ser observadas sob a ótica das exigências Revista Brasileira de Políticas Públicas e Internacionais, v.3, n.2, Dezembro/2018, pp. 01-28. 
VALE, Andressa Ramos Vieira; PEREIRA, Wellington. Disputas e Barreiras NãoTarifárias no Comércio Agrícola: as exportações de carne bovina brasileira entre 2006 e 2015.

técnicas/religiosas para o abate e comercialização. O Brasil e o Irã iniciaram a expansão de suas relações econômicas bilaterais no começo dos anos 1990 e desde 2003 o Brasil se tornou um dos principais parceiros comerciais do Irã na América Latina. O Irã possui uma população estimada em 73,6 milhões de pessoas e faz intercâmbio comercial com mais de 130 países (MRE, 2012b).

Os principais produtos exportados para o Irã são milho, soja e derivados, carnes, açúcar, chassis de automóveis, carrocerias de automóveis, sucos de laranja e fumo. Já as importações provenientes de lá são, principalmente, ureia, borracha, uvas secas, pistaches, mármore, tapetes de lã, sucos e extratos de alcaçuz e objetos de vidro (SECEX, 2016).A balança comercial brasileira com o Irã é superavitária entre 2006 e 2015, atingindo o ápice em 2011 com US\$ 2,2 bilhões. O menor superávit ocorre em 2009, com US\$ 1,1 bilhões.

Para importar bens no Irã é necessária uma licença geral do Ministério do Comércio e aprovação do Ministério pertinente, dependendo do tipo de produto a ser importado. O mercado é aberto para commodities de primeira necessidade, bens de capital, peças de reposição e matérias-primas. Porém, todas as agências governamentais estão proibidas de importar produtos que são produzidos internamente (MRE, 2012).

O Irã estabeleceu um piso de 4\% para as tarifas, e o governo pode determinar tarifas a partir desse piso para as diferentes mercadorias, levando em consideração a proteção necessária para a produção local e os interesses do consumidor. As tarifas variam de $0 \%$ para as commodities básicas até 100\% para alguns produtos de consumo. Não há outros impostos, tarifas ou encargos incidentes sobre os produtos importados, exceto os "impostos de importação”, ou seja, não são aplicados quotas ou contingenciamentos (MRE, 2012b).

Diferentemente dos casos referentes à União Europeia e à Rússia, as exportações de carne bovina para o Irã são objetos de análise porque as adequações exigidas a uma nação podem representar, inclusive, um empecilho na oferta de um produto. As carnes com o abate

Revista Brasileira de Políticas Públicas e Internacionais, v.3, n.2, Dezembro/2018, pp. 01-28. 
VALE, Andressa Ramos Vieira; PEREIRA, Wellington. Disputas e Barreiras NãoTarifárias no Comércio Agrícola: as exportações de carne bovina brasileira entre 2006 e 2015.

diferenciado, sob os preceitos religiosos do halal $^{2}$ ganham espaço nas grandes empresas produtoras brasileiras, o que permite a elas terem maior competitividade nesse mercado. As carnes bovinas e de aves são permitidas no mercado iraniano desde que abatidos sob os preceitos religiosos. Para os islâmicos, o abate deve ser exclusivamente pela degola para garantir a morte instantânea do animal, e deve ser realizado por mulçumano praticante, em geral árabe (Portal Brasil, 2011).

Figura 5 - Exportações de carne bovina brasileira para o Irã entre 2006 e 2015 (US\$bilhões e em mil tons)

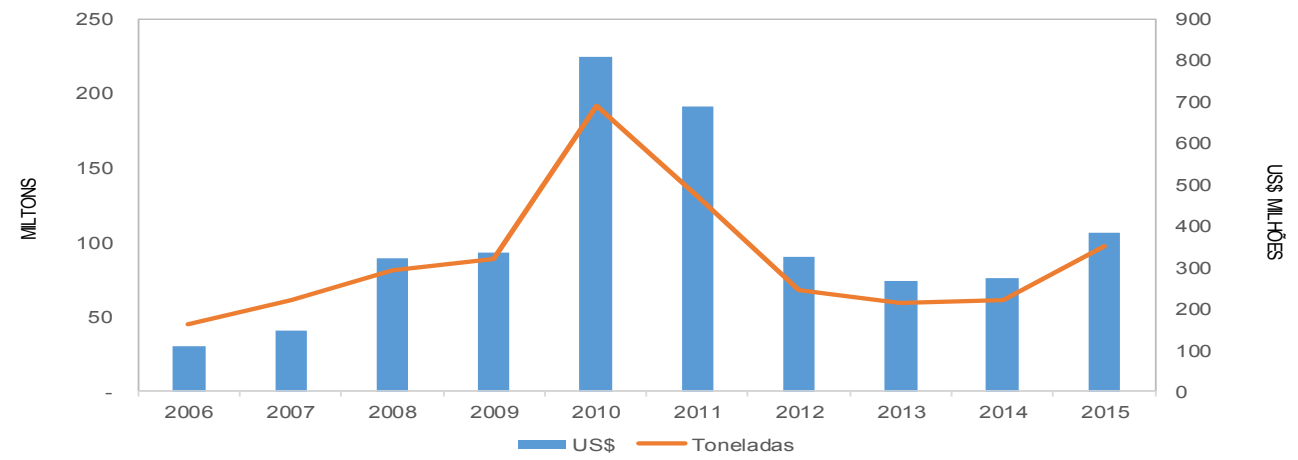

FONTE: elaboração própria a partir de SECEX (2016).

A Figura 5 mostra as exportações de carne bovina para o Irã entre 2006 e 2015. Verifica-se que as exportações tiveram seu ápice em 2010, resultado da adequação de mais frigoríficos brasileiros às exigências iranianas, o que permitiu alcançar a venda de mais de 191 mil toneladas. A queda em 2012 ocorreu devido a um embargo iraniano às carnes do estado do Paraná após a notícia de um foco de febre aftosa atípico no local. A suspensão do embargo se deu no início do ano de 2016 e os produtores paranaenses já esperavam aumento considerável das quantidades a serem exportadas (MAPA, s/d).

\footnotetext{
${ }^{2}$ Na prática, o termo halal significa permitido para consumo, mas o conceito ultrapassa o simples consentimento, tratando de princípios que vão do respeito a todos os seres vivos até questões sanitárias. A preocupação com a higiene do alimento se estende ao bem-estar do animal (PORTAL BRASIL, 2011).
}

Revista Brasileira de Políticas Públicas e Internacionais, v.3, n.2, Dezembro/2018, pp. 01-28. 
VALE, Andressa Ramos Vieira; PEREIRA, Wellington. Disputas e Barreiras NãoTarifárias no Comércio Agrícola: as exportações de carne bovina brasileira entre 2006 e 2015.

Os três casos analisados e suas especificidades apresentadas anteriormente exemplificam bem a dinâmica do comércio internacional da carne bovina. A melhoria da cadeia de produção nacional juntamente com a adequação das exigências sanitárias e culturais dos parceiros comerciais como a União Europeia e o Irã demonstram uma maneira de dirimir os efeitos das barreiras comerciais administrativas, transformando entraves em vantagens. A aproximação nacional a grandes economias como a Rússia e o Irã demonstram que a posição política internacional mais neutra pode gerar também bons resultados comerciais. Porém, outro ponto conclusivo da análise do comércio com os três casos apresentados é que as economias dependentes do setor agroexportador são reféns de muita volatilidade das quantidades comercializadas, que mudam de acordo com o momento político e econômico das nações importadoras, e que a diversificação tanto da pauta de exportações quanto dos parceiros comerciais tem gerado melhores resultados.

\section{Considerações finais}

Sabe-se que as práticas protecionistas podem ter como finalidade a proteção de um setor doméstico ineficiente, o aumento da qualidade sanitária dos produtos, ou mesmo podem ter natureza política, cultural e religiosa. Sejam intencionais ou não, as barreiras são restrições importantes ao comércio e a adequação das exigências internacionais é uma variável crucial para que um país se mantenha como referência na exportação de algum produto.

A União Europeia, com suas práticas de subsídios não causa grande impacto nos preços internacionais, mas os países deste bloco acabam controlando as quantidades ofertadas em seus mercados internos, influenciando os preços e dificultando a inserção de produtos de países em desenvolvimento. Suas medidas fitossanitárias forçam o aumento da qualidade da produção, mas excluem os produtores que, de acordo com os níveis de preços internacionais, não recebem o retorno adequado frente ao aumento de custos gerados pela aplicação das exigências técnicas. A Rússia e sua volatilidade política com o Ocidente influencia, positivamente ou não, as relações comerciais com a América Latina. O embargo russo à carne da União Europeia desde 2014 foi prorrogado até o final de 2017. Visto que no ano de 2011, a maioria da carne

Revista Brasileira de Políticas Públicas e Internacionais, v.3, n.2, Dezembro/2018, pp. 01-28. 
VALE, Andressa Ramos Vieira; PEREIRA, Wellington. Disputas e Barreiras NãoTarifárias no Comércio Agrícola: as exportações de carne bovina brasileira entre 2006 e 2015.

consumida na Rússia veio do continente europeu, ficando aberto um mercado potencial maior para o Brasil. Ademais, os países árabes estão desenvolvendo uma boa relação comercial com o Brasil nos últimos anos. Ao reservar atenção especial às suas exigências religiosas e culturais, os frigoríficos brasileiros têm grande chance de expansão de suas exportações de carnes, principalmente, agora com o fim do embargo iraniano aos frigoríficos paranaenses.

Os três casos examinados demonstram as dificuldades que um grande país agroexportador como o Brasil tem para se ajustar às diferentes e voláteis exigências dos mercados internacionais. A adequação às exigências se tornou a melhor resposta a um sistema cada vez mais competitivo e dinâmico. As práticas protecionistas administrativas são difíceis de serem reguladas, pois se confundem com a soberania das nações e com suas características econômicas, políticas e culturais. A sensibilidade econômica do setor agropecuário desencadeia uma elevada proteção, e os países de alta renda penalizam os níveis de preços internos e os gastos públicos em prol da manutenção interna do setor, dos empregos e da renda gerada por ele. Ao se analisar as características econômicas, sanitárias, políticas e culturais dos parceiros econômicos relatados anteriormente, é possível concluir que a total liberalização econômica não é possível e nem ideal. Cabe aos países agroexportadores a manutenção da competitividade através da qualidade produtiva e uma participação incisiva junto à OMC de modo a mitigar as injustiças comerciais.

\section{Referências}

Andrade, P. C. (2010). A vitória do Brasil na OMC e suas implicações para os países em desenvolvimento. Revista Mundorama, Brasília, p.1-3.

ABIEC - Associação Brasileira das Indústrias Exportadoras de Carnes. s/d. Disponível em: http://www.abiec.com.br/Exportacoes.aspx. Acesso em: 16 nov. 2017.

Barral, W.; Amaral, R. (2015). Fim do contencioso do algodão: lições de uma disputa na OMC. Revista Brasileira de Comércio Exterior, Rio de Janeiro, n. 122, p. 13-16, jan./mar. 2015.

Beefpoint. UE registra novos casos de doença da "vaca louca". 27 de abril de 2010. Disponível em: <http://www.beefpoint.com.br/cadeia-produtiva/giro-do-boi/ue-registra-novoscasos-da-doenca-da-vaca-louca-62311/> . Acesso em: 20 de nov. 2017.

Revista Brasileira de Políticas Públicas e Internacionais, v.3, n.2, Dezembro/2018, pp. 01-28. 
VALE, Andressa Ramos Vieira; PEREIRA, Wellington. Disputas e Barreiras NãoTarifárias no Comércio Agrícola: as exportações de carne bovina brasileira entre 2006 e 2015.

Bruno, F. M.; Azevedo, A. F. e Massuquetti, A. (2014). Os contenciosos comerciais e os principais casos de retaliação do Brasil à prática de subsídios agrícolas na Organização Mundial do Comércio. Revista Ciência Rural, Santa Maria, v.44, n.1, p. 188-195, jan. 2014.

. (2012). Os subsídios à agricultura no comércio internacional: as políticas da União Europeia e dos Estados Unidos da América. Revista Ciência Rural, Santa Maria, v.42, n.4, p.757-764, abr. 2012.

CE - Comissão Europeia. (2016). Diretoria Geral de Agricultura e Desenvolvimento Rural. Agri-Food Trade StatisticalFactsheet: European Union - Brazil. Luxemburgo: Serviço das Publicações da União Europeia.

Contini, E.; Talamini, D. (2005). Carnes do Brasil? A União Europeia estremece! Revista de Política Agrícola, Brasília, n.1, p. 47-61, jan./fev./mar. 2005.

FAO - Organização das Nações Unidas para Agricultura e Alimentação. s/d. Disponível em: <http://faostat3.fao.org/download/Q/*/E>. Acesso em 19 nov. 2017.

Florindo, T.; Medeiros, G.; e Mauad, J. (2015). Análise das barreiras não tarifárias à exportação de carne bovina. Revista de Política Agrícola, v. 24, n. 2, p. 52-63, 2015.

Galvão, M. B. A.; Abreu, M. D.; Pimentel, F. M. (2015). O relançamento das negociações da Rodada de Doha. Revista Brasileira de Comércio Exterior, Rio de Janeiro, n. 122, p. 6-12, jan./mar. 2015.

Gonçalves, S. R. M.; Silva, A. L. M. da; Simoes, R. C. F. (2006). A Importância do GATT no Comércio Internacional. Disponível em: http://www.unimep.br/phpg/mostraacademica/anais/4mostra/pdfs/463.pdf. Acesso em 14 nov. 2017.

International Beef Alliance (IBA). s/d. Disponível em: <http://internationalbeefalliance.com/about-us.html>. Acesso em: 28 nov. 2017.

Jornal do Senado. (2008). Surto de “vaca louca” na Europa tornou controle mais rígido. Jornal do Senado. Ano XIV — No 2.746/160 — Brasília, 18 a 24 de fevereiro de 2008.

Kuzmin, V. (2014). Rússia barra importação de carne da Austrália por uso de estimulador. Gazeta Russa. Disponível em: $<$ http://gazetarussa.com.br/economia/2014/04/09/russia_barra_importacao_de_carne_da_austra lia_por_uso_de_estimulador_25051> Acesso em 16 nov. 2017.

Krugman, P. e Obstfeld, M. (2010). Economia Internacional: teoria e política. 8. ed. São Paulo: Pearson Prentice Hall.

Lamy, P. (2014). A Organização Mundial do Comércio: novas questões, novos desafios. Revista Brasileira de Comércio Exterior, Rio de Janeiro, n. 121, p. 4-19, out./dez. 2014.

Lelis, M. e Amaral, M. (2012). Do "novo protecionismo" ao "protecionismo privado": a atuação da sociedade civil na regulação do comércio internacional. Brasília: Apex-BRASIL,

Revista Brasileira de Políticas Públicas e Internacionais, v.3, n.2, Dezembro/2018, pp. 01-28. 
VALE, Andressa Ramos Vieira; PEREIRA, Wellington. Disputas e Barreiras NãoTarifárias no Comércio Agrícola: as exportações de carne bovina brasileira entre 2006 e 2015.

2012. Disponível em: www.apexbrasil.com.br/Content/imagens/91c4c2a3-e121-4a36-94827e24e4d3c905.pdf. Acesso em: 28/02/2018.

Lima-Campos, A. de. (2015). Em agricultura, é hora de agir com acordos plurilaterais. Revista Brasileira de Comércio Exterior, Rio de Janeiro, n. 122, p. 17-19, jan./mar. 2015.

Lossan, A. e Damarcos, M. (2014). Guerra moderna é econômica. Gazeta Russa. Disponível em: <http:/gazetarussa.com.br/economia/2014/08/20/guerra_moderna_e_economica_26999>. Acesso em: 15 nov. 2017.

MAPA. Ministério da Agricultura, Pecuária e Abastecimento. s/d. Disponível em: http://www.agricultura.gov.br/vegetal/exportacao. Acesso em: 13 nov. 2017.

Miranda, S. H. G. (2001). Quantificações dos efeitos das barreiras não-tarifárias sobre as exportações brasileiras de carne bovina. Tese ESALQ-USP.

MRE. Ministério das Relações Exteriores (MRE). (2012a). Departamento de promoção do comércio exterior. Como exportar União Europeia. Bruxelas: MRE. (Como exportar, n.217).

. Ministério das Relações Exteriores (MRE). (2012b). Departamento de promoção do comércio exterior. Como exportar Irã. Teerã: MRE. (Como exportar).

. Ministério das Relações Exteriores (MRE). (2013). Departamento de promoção do comércio exterior. Como exportar Rússia. Moscou: MRE. (Como exportar, n.222).

Nassar, A. M.; Bachion, L. C.; e Zambianco, W. M. (2014). Impactos das políticas agrícolas dos EUA e da UE no agronegócio brasileiro. Revista Brasileira de Comércio Exterior, Rio de Janeiro, n. 121, p. 34-37, out./dez. 2014.

Nunes, A. e Molina, F. (2013). União Europeia e as restrições para a importação da carne bovina brasileira. Florianópolis: ONIAL. Disponível em: $<$ https://onial.wordpress.com/2013/08/19/uniao-europeia-e-as-restricoes-para-a-importacao-dacarne-bovina-brasileira/> . Acesso em: 17 nov. 2017.

Paula, L. F. e Ferrari Filho, F. (2011). Desdobramentos da crise financeira internacional. Revista de Economia Política. São Paulo, v. 1, n.2, p. 315-335, abr./jun 2011.

Portal Brasil. (2011). Indústrias brasileiras fazem abate religioso de carnes para garantir mercados estrangeiros. Disponível em: <http://www.brasil.gov.br/economia-eemprego/2011/01/industrias-brasileiras-fazem-abate-religioso-de-carnes-para-garantirmercados-estrangeiros>. Acesso em: 15 nov. 2017.

Rego, E. C. L. (1996). Do GATT à OMC: O que mudou como funciona e para onde caminha o Sistema Multilateral de Comércio. Revista BNDES, Rio de Janeiro, n. 6, p. 1-21, dez. 1996.

Rodrigues, T. e Paula, N. (2008). A agricultura nas negociações multilaterais da Rodada Doha e suas implicações para o Brasil. Revista de Economia, v. 34, n. 2 (ano 32), p. 95-115, maio/ago. 2008.

Revista Brasileira de Políticas Públicas e Internacionais, v.3, n.2, Dezembro/2018, pp. 01-28. 
VALE, Andressa Ramos Vieira; PEREIRA, Wellington. Disputas e Barreiras NãoTarifárias no Comércio Agrícola: as exportações de carne bovina brasileira entre 2006 e 2015.

Sbarai, N. e Miranda, S. (2014). Tarifas equivalentes de medidas não tarifárias sobre exportações brasileiras de carne bovina para a UE (2000-2010). Revista de Economia $e$ Sociologia Rural, v. 52, n. 2, p. 267-284, 2014.

SECEX. Secretaria de Comércio Exterior. s/d. Disponível em: <http://www.mdic.gov.br/comercio-exterior/estatisticas-de-comercio-exterior/balancacomercial-brasileira-mensal-2>. Acesso em: 16 nov. 2017.

Silva, S. Z. da; Triches, D.; Malafaia, G. (2011). Análise das barreiras não tarifárias à exportação na cadeia da carne bovina brasileira. Revista de Política Agrícola, Brasília, n. 2, p. 23-39, abril/maio/jun. 2011.

Thorstensen, V. H. (2001). OMC - Organização Mundial do Comércio: as regras do comércio internacional e a nova rodada de negociações multilaterais. 2. ed. rev. e ampliada. São Paulo: Edições Aduaneiras.

Thukral, N. e Patton, D. (2014). China busca carne bovina para saciar apetite da classe média. Revista Exame. São Paulo. 18 mar. 2014. Disponível em: <http://exame.abril.com.br/economia/china-busca-carne-bovina-para-saciar-apetite-da-classemedia-brasil-e-opcao/>. Acesso em: 16 nov. 2017.

UNCTAD - Conferência das Nações Unidas sobre Comércio e Desenvolvimento. s/d. Disponível em: $<$ http://unctadstat.unctad.org/wds/ReportFolders/reportFolders.aspx?IF_ActivePath=P,15912\& sCS_ChosenLang=en>. Acesso em: 19 nov. 2017.

Revista Brasileira de Políticas Públicas e Internacionais, v.3, n.2, Dezembro/2018, pp. 01-28. 